\title{
Electrocoagulation treatment of swine slaughterhouse wastewater: effect of electrode material
}

\author{
Kathlia D. Cruz ${ }^{1,2 *}$, Janine Therese J. Francisco ${ }^{2}$, Kristine Jhalene M. Mellendrez ${ }^{2}$, and Jermaine Marianne F. Pineda ${ }^{2}$ \\ ${ }^{1}$ School of Chemical, Biological, and Materials Engineering and Sciences, Mapúa University, Muralla St., Intramuros, Manila, \\ Philippines 1002 \\ ${ }^{2}$ Water Quality and Wastewater Research Laboratory, Mapúa University, Muralla St., Intramuros, Manila, Philippines 1002
}

\begin{abstract}
A slaughterhouse is one of the main sources of wastes in meat establishments where animals are killed for consumption as food products. Slaughtering animal processing industries generate a large volume of wastewaters containing very high concentrations of organic matter. In this study, the effect of various electrode materials on the electrocoagulation efficiency was investigated for the treatment of swine slaughterhouse wastewater. These electrodes include pure aluminum $(\mathrm{Al})$, pure iron $(\mathrm{Fe})$ and combination of aluminum - iron $(\mathrm{Al}-\mathrm{Fe})$. The performance of these electrodes was investigated in terms of electrocoagulation time, COD removal, electrode consumption, and current density. Additional parameters were also checked before and after treatment such as conductivity, turbidity, BOD, oil and grease, TSS and settleable solids. All electrodes gave more than $90 \%$ COD removal however, the pure aluminum electrode is the most efficient (97\% removal). It also gave the least electrode consumption. Furthermore, the most efficient current density and time were found to be $25 \mathrm{~mA} / \mathrm{cm}^{2}$ and 100 minutes respectively. Overall the electrocoagulation treatment of swine slaughterhouse wastewater was successful in terms of reduction of all the parameters considered.
\end{abstract}

\section{Introduction}

Slaughterhouse wastewater has a complex composition and if not properly treated could pose a threat to the environment and could be a health hazard. It has high concentrations of biodegradable organic compounds such as blood and protein, total suspended solids like grease, fats, hair, feather, flesh, manure, grit and undigested feeds, high alkalinity, nitrogen, phosphorus, micronutrients, pathogenic bacteria and other inorganic compounds that leads to high BOD and COD [1-3]. A wide range of wastewater treatments such as biological processes, filtration, air stripping, ion-exchange, chemical precipitation, chemical oxidation, carbon adsorption, ultrafiltration, reverse osmosis, electrodialysis, volatilization, and gas stripping have been used and applied for slaughterhouse wastewater. Recently, promising techniques based on electrochemical technology are being developed and existing ones are being improved to the extent of no further chemical additions. These include electrocoagulation and electrofloatation [4]. Electrocoagulation has become an attractive and suitable method for the treatment of different kinds of wastewater due to its environmental compatibility, versatility, energy efficiency, safety, selectivity, amenability to automation, and cost effectiveness. In particular, it has gained popularity in the treatment of different types of slaughterhouse wastewater [5-8].
This research evaluated the potential of using EC method in the treatment of local swine slaughterhouse wastewater. This study designed an electrocoagulation system taking into account the electrode arrangement, current density and the treatment time while holding the temperature and $\mathrm{pH}$ of the wastewater constant. The effects of these parameters in terms of oil and grease, BOD5 and COD removal as well as the electrode consumption were investigated. The results were discussed herein.

\section{Methodology}

\subsection{Materials and wastewater}

The wastewater used throughout this study was taken from a local swine slaughterhouse in the city of Parañaque (Philippines). The slaughterhouse capacity is typically 2 pigs per day, generating approximately 30 liters of wastewater daily. Slaughtering of the pigs occur every morning from 6 to $8 \mathrm{AM}$. The effluents coming from different slaughterhouse operations such as stabbing, dehairing, blood collecting, gutting and washing were all collected in a "kawa" or large vat, and maintained in uniform mixing. Collection of samples was taken after all the pigs had been slaughtered. Prior to sample collection, the wastewaters were filtered to remove hairs and large solids. The samples were stored in glass bottles, preserved by adding concentrated

* Corresponding author: kathliadcastro@gmail.com 
sulfuric acid, $\mathrm{H}_{2} \mathrm{SO}_{4}$ to $\mathrm{pH}$ less than 2, shipped cold and kept at $4{ }^{\circ} \mathrm{C}$ before use. The storage period including analysis before starting experiments varied from one day to 7 days according to the Standard Methods. Initial characterization of the swine slaughterhouse wastewater was performed to determine the $\mathrm{pH}$, conductivity, turbidity, COD, BOD, oil and grease, TSS and settleable solids, following the procedures of the Standard Methods.

\subsection{Experimental set - up}

The experimental setup is given in Figure 1. The Pyrex beaker used as electrocoagulator with a height of 152.4 $\mathrm{mm}$ and a diameter of $79.375 \mathrm{~mm}$ was equipped with two parallel monopolar electrodes; 1 anode and 1 cathode with the dimensions of $38 \mathrm{~mm} \times 70 \mathrm{~mm} \times 2 \mathrm{~mm}$ made of aluminum or iron plates. The total effective electrode area was $22.8 \mathrm{~cm}^{2}$ and the spacing between electrodes was $3 \mathrm{~cm}$. The electrodes were connected to a DC digital regulated power supply GW Dual Tracking (GPC-3030D) with potentiostatic or galvanostatic operational options. Prior to each experimental run, these electrodes were washed with acetone for the surface grease removal, after which these were dried and weighed to constant mass. Three configurations of electrode were tested for effectiveness assessment such as: (1) two iron electrodes (Fe-Fe); (2) two aluminum electrodes (Al-Al) and (3) 1 iron electrode and 1 aluminum electrode $(\mathrm{Fe}-\mathrm{Al})$. In the experiment, the iron anode was used with an iron cathode; the aluminum anode with the aluminum cathode; and the aluminum anode with the iron cathode. All runs were performed at constant temperature of $25^{\circ} \mathrm{C}$, at constant mixing speed of $200 \mathrm{rpm}$, and with a $200 \mathrm{~mL}$ wastewater solution. The treated solution was filtered and the filtrate was analyzed. The detailed specifications of electrocoagulation reactor were listed on Table 1. After determining the most effective electrode configuration, the reactor was scaled up to $2 \mathrm{~L}$ to verify the effectiveness of the design in the larger scale set-up. The EC specifications were sized up proportionately based on the specifications in Table 1.

\subsection{Wastewater analysis}

After the EC treatment several parameters such as COD, BOD, TSS, turbidity, oil and grease, $\mathrm{pH}$ and conductivity were checked according to the Standard Methods. COD was analysed using the closed refluxed, colorimetric method by the absorbance generated using UV-VIS spectrometer (Perkin Lambda 40). The oil and grease removal was determined by Hexane Extractable Gravimetric Method. The TSS was also determined by Gravimetric Method, the $\mathrm{pH}$ using OHAUS $\mathrm{pH}$ meter (starter 2000 model), the turbidity using Portable Data Logging Spectrophotometer DR/2010 Hach, and the BOD5 using BOD sensor. For the conductivity determination, Eutech Instruments Con51 model conductivity meter was used.

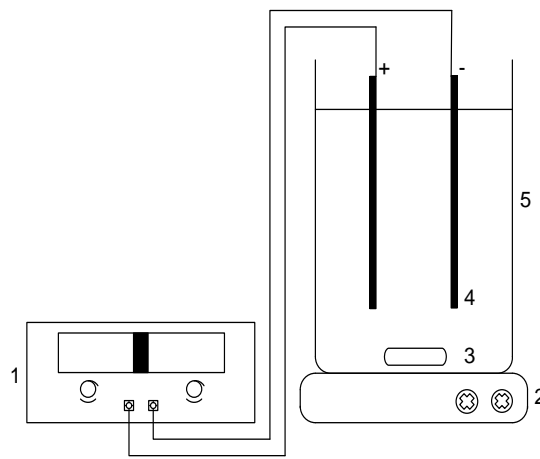

A

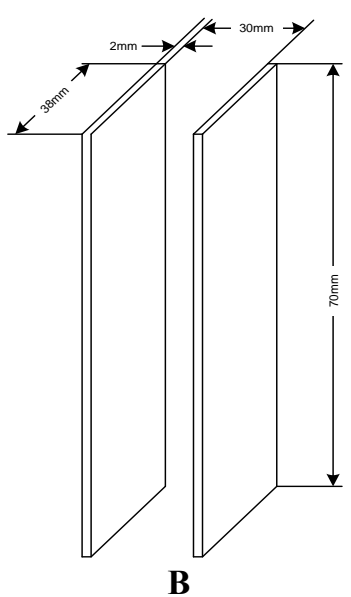

Fig. 1. A. Electrocoagulation set-up: (1) DC power supply, (2) Hot plate with magnetic stirrer, (3) Magnetic bar stirrer, (4) Electrodes, Electrochemical cell; B. Electrode dimensions

Table 1. Electrocoagulation reactor specifications

\begin{tabular}{|c|c|c|}
\hline \multirow{2}{*}{ Parts } & \multicolumn{2}{|c|}{ Specifications } \\
\hline & Small Scale & Large Scale \\
\hline Electrode & \\
\hline Material & \multicolumn{2}{|c|}{ Iron and Aluminum } \\
\hline Type & \multicolumn{2}{|c|}{ Strip type } \\
\hline Shape & \multicolumn{2}{|c|}{ Rectangular plate } \\
\hline Number & \multicolumn{2}{|c|}{2} \\
\hline Plate & \multicolumn{2}{|c|}{ Parallel } \\
\hline $\begin{array}{l}\text { Connection } \\
\text { Conrangement }\end{array}$ & \multirow{2}{*}{\multicolumn{2}{|c|}{ Monopolar parallel }} \\
\hline Mode & & \\
\hline Attachment & \multicolumn{2}{|c|}{ Detachable } \\
\hline Size & $38 \mathrm{~mm} \times 70 \mathrm{~mm}$ & $85 \mathrm{~mm} \times 140 \mathrm{~mm}$ \\
\hline Thickness & $2 \mathrm{~mm}$ & $3 \mathrm{~mm}$ \\
\hline Effective & & \\
\hline $\begin{array}{l}\text { electrode surface } \\
\text { area }\end{array}$ & $22.8 \mathrm{~cm}^{2}$ & $56.95 \mathrm{~cm}^{2}$ \\
\hline Electrode gap & $30 \mathrm{~mm}$ & $45 \mathrm{~mm}$ \\
\hline \multicolumn{3}{|l|}{ Reactor } \\
\hline Vessel Material & \multicolumn{2}{|c|}{ Glass } \\
\hline Reactor mode & \multicolumn{2}{|c|}{ Batch mode } \\
\hline Dimensions & $\begin{array}{l}\text { Diameter: } 79.375 \\
\text { Height: } 152.4 \mathrm{~mm}\end{array}$ & $\begin{array}{c}\text { Diameter: } 130.175 \mathrm{~mm} \\
\text { Height: } 190.5 \mathrm{~mm}\end{array}$ \\
\hline Total volume & $600 \mathrm{~mL}$ & $2000 \mathrm{~mL}$ \\
\hline $\begin{array}{l}\text { Wastewater } \\
\text { Volume }\end{array}$ & $200 \mathrm{~mL}$ & $1700 \mathrm{~mL}$ \\
\hline Temperature & \multicolumn{2}{|c|}{$25^{\circ} \mathrm{C}$ (room temperature) } \\
\hline Mixing speed & \multicolumn{2}{|c|}{$200 \mathrm{rpm}$} \\
\hline \multicolumn{3}{|l|}{ Power supply } \\
\hline Voltage & \multicolumn{2}{|c|}{$30 \mathrm{~V}$} \\
\hline Current & \multicolumn{2}{|c|}{$6 \mathrm{~A}$} \\
\hline
\end{tabular}




\section{Results and Discussion}

\subsection{Electrode material}

Electrochemical waste treatment method like electrocoagulation (EC), depends heavily on the electrode's characteristics used during the process such as electrode material, geometry and configuration [9]. In this research, different electrode materials such as aluminum, iron and the combination of both were considered. Aluminum and iron are the most common electrode materials used in EC due to its availability, cheap cost and proven effectivity [10]. To determine its efficiency the \%COD removal was measured at constant current density of $25 \mathrm{~mA} / \mathrm{cm}^{2}$ (maximum allowed by the power supply used), $\mathrm{pH}$ of 2, speed of $200 \mathrm{rpm}$ and temperature at $25^{\circ} \mathrm{C}$ at varying electrocoagulation time. COD is an indicator of the degree of pollution in the effluent and of the potential environmental impact of the discharge of wastewater in bodies of water [11]. As depicted in Figure 2, the \%COD removal increases with time for all electrode materials considered wherein the pure $\mathrm{Al}$ electrodes had the highest \%COD removal of 97\% while pure Fe had the lowest and the combination was intermediate of the two. For pure $\mathrm{Al}$ and $\mathrm{Al}-\mathrm{Fe}$ combination the \%COD removal created a plateau at 100 minutes while for pure $\mathrm{Fe}$ it took 160 minutes to establish a plateau. This results showed that the amount and rate of \%COD removal was $\mathrm{Al}>\mathrm{Al}-\mathrm{Fe}>\mathrm{Fe}$. Using ANOVA at $95 \%$ confidence level, it was found that there was a significant difference in mean mass for both electrode type and treatment time. Thus, the type of electrode material should be considered in the EC reactor design. To support these findings the electrode consumption was also considered in this study.

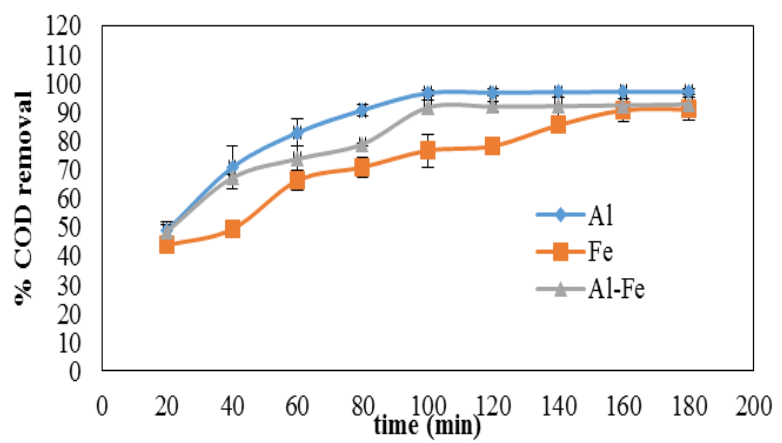

Fig. 2. Percent COD removal using various electrode as a function of time at $25 \mathrm{~mA} / \mathrm{cm} 2$ currenrt density

During electrolysis, the electrical current causes the dissolution of metal electrodes such as iron and aluminum producing ions into the wastewater. The released ions formed coagulated species of metal hydroxides that destabilize and aggregate the suspended particles or precipitate and adsorb dissolved contaminants [12]. Shown in Figure 3 was the electrode consumption during the EC process and it was evident that $\mathrm{Al}-\mathrm{Al}$ has the least electrode consumption followed by $\mathrm{Al}-\mathrm{Fe}$ and the $\mathrm{Fe}-\mathrm{Fe}$ has the highest electrode consumption. According to Faraday's law, the amount of coagulant is directly proportional with treatment time, current applied and molecular weight of metal. Thus, Fe has the highest electrode consumption, producing more coagulant compared to Al. However, this contradicts in terms of \% COD removal because $\mathrm{Al}$ has the greatest. Presumably, because aluminum has higher reactivity and large negative potential making it easily oxidized than iron, thereby producing more ions in the solutions readily leading to a faster coagulation and thus, make the $\%$ COD removal higher than iron. Likewise, this tendency of aluminum to oxidize spontaneously could lead to the formation of aluminum oxide that suppress further unnecessary oxidation resulting to lower electrode consumption. Economically the lower electrode consumption is favorable, thus aluminum is the most appropriate electrode to use.

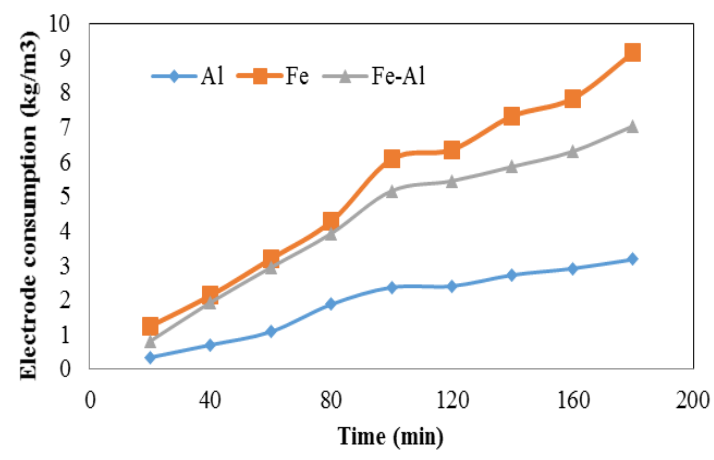

Fig. 3. Electrode consumption using various type of electrode materials as a function of time at 25 $\mathrm{mA} / \mathrm{cm}^{2}$ currenrt density

Furthermore, during the treatment process, the color changes of the wastewater were also observed. The color improved from dark-brown to nearly transparent white with respect to time using aluminum electrodes. Based on electrochemistry principles, the anode is oxidized by means of losing electrons, while the water is reduced by gaining electrons, thereby making the wastewater better treated. When the anode electrode was in contact with the slaughterhouse wastewater, small particles of the metal were released and the particulates were neutralized by the formation of hydroxide complexes forming agglomerates. These particulates floated to the top of the electrochemical cell by means of the hydrogen bubbles created from the cathode, leaving the wastewater clearer. The floated particulates can be skimmed from the top of the reactor [13]. On the other hand, the treated effluent with pure iron electrodes turned up greenish first and then turned yellow and turbid. This green and yellow color may resulted from $\mathrm{Fe}^{2+}$ and $\mathrm{Fe}^{3+}$ ions produced during the EC process. $\mathrm{Fe}^{2+}$ is commonly generated ion in situ during electrolysis of iron electrode. It has relatively high solubility at acidic or neutral conditions and can be oxidized easily into $\mathrm{Fe}^{3+}$ by dissolved oxygen in water [14]. 


\subsection{Effect of current density}

The efficiency of electrocoagulation process is largely influenced by current because it dictates the rate of coagulant dosage, rate and size of bubble production as well as the growth of flocs [1]. Therefore, the effect of current density on the \% COD removal was investigated under the same operating conditions and the determined maximum time (100 minutes). Different current densities in the range of $10-25 \mathrm{~mA} / \mathrm{cm}^{2}$ with $5-\mathrm{mA} / \mathrm{cm}^{2}$ increments were investigated using the three different electrode types. As shown in Figure 4, \% COD removal increased with increasing current density wherein pure Al (97\%) had the highest removal followed by Al-Fe $(92 \%)$ and lastly with pure $\mathrm{Fe}(77 \%)$. This observation is similar to the observation of Teczan et al in 2009 [15] in his study on cattle slaughterhouse wastewater. At higher current, the amount of metal oxidized increased, resulting in a greater amount of precipitate for the removal of pollutants. In addition, it was demonstrated that bubble densities increases and their size decreases with increasing current density resulting in a greater upwards flux and a faster removal of pollutants and sludge flotation [16]. However, it is advisable to limit the current density in order to avoid excessive oxygen evolution as well as to eliminate other adverse effect, like heat generation [17].

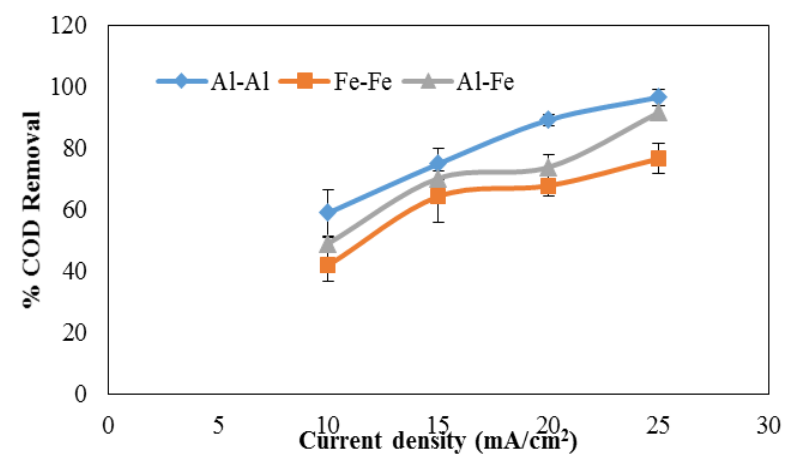

Fig. 4. Effect of current density on \% COD removal for various electrode types at 100 minutes

\subsection{Larger scale waste water treatment}

In order to determine effectiveness of the optimum operating conditions for treatment of swine slaughterhouse wastewater, the reactor was scaled up to $2 \mathrm{~L}$ and the initial and final parameters were compared. Shown in table 2 was the result of the initial and after treatment of swine slaughterhouse wastewater. The acidity of the solution was due to the addition of $\mathrm{H}_{2} \mathrm{SO}_{4}$ to store and preserve the wastewater prior to EC. The adjusted $\mathrm{pH}$ was maintained in the process. The conductivity of solution depends both on the type and concentration of electrolyte present in the solution. Increase in applied current increases the coagulant dosage and therefore increases the conductivity of the solution. Similarly the solution has high COD that was reduced dramatically after EC treatment. EC involved the generation of coagulant in situ by the dissolution of metal from the anode with simultaneous formation of aluminum or iron hydroxides and hydrogen gas at the cathode. The generated gas helped in the flocculation of particles and organic matter at the water surface thereby reducing COD. Oil and grease are found in wastewater either as an emulsion or as free-floating agglomerates that causes sewer blockages, leading to spills and overflows that are hazardous to health and environment. They are similar to Total Suspended Solids and their removal was caused by the hydrogen gas generated from the cathode that floats the flocculated particles and organic matter. One component of water quality, total suspended solids (TSS), is known to be a very important part of physical degradation and a good indicator of other pollutants. Using electrocoagulation, the amount of TSS from initial to final had significantly decreased. The process separated the solids from the water molecule. Also, TSS removal efficiency was found to be a function of the amount of metal generated which can be determined by the process of time [18]. Another positive result was observed in the turbidity value. From 850 NTU, it went down to 91 NTU after the EC process. This trend is the same with the TSS results. The turbidity decreases as the coagulant dose increases. Destabilization takes place when coagulant dose is increased up to a certain point in time which was found to affect the residual turbidity. Also, there was a study that confirms the existence of a strong linear relationship between turbidity and total suspended solids (TSS) concentration [19]. On the other hand, BOD amount decreased from $556.25 \mathrm{mg} / \mathrm{L}$ to $111.81 \mathrm{mg} / \mathrm{L}$ after treating the wastewater using EC. The study also obtained a good outcome for the settleable solids. It was investigated that the value after treatment of electrocoagulation was no longer measurable. The following are the effluent standards imposed by the Philippine DENR Executive No. 35: pH (6.0-9.0), COD $(200 \mathrm{mg} / \mathrm{L})$, BOD $(120 \mathrm{mg} / \mathrm{L})$, TSS $(150 \mathrm{mg} / \mathrm{L})$ and Oil and grease $(15 \mathrm{mg} / \mathrm{L})$. All the effluent parameters conformed to these standards except for $\mathrm{pH}$.

Table 2. Characterization of initial and treated slaughterhouse wastewater

\begin{tabular}{lcc}
\hline Parameters & Initial & $\begin{array}{c}\text { Treated } \\
\text { (scale - up, 2L) }\end{array}$ \\
\hline $\mathrm{pH}$ & 8.13 & 2.43 \\
Conductivity $\left(\mathrm{ms} \cdot \mathrm{cm}^{-1}\right)$ & 2.13 & 4.36 \\
Turbidity (NTU) & 850 & 91 \\
COD (mg/L) & 1239 & 41.67 \\
BOD (mg/L) & 556.45 & 111.81 \\
Oil and Grease (mg/L) & 86.13 & 17.43 \\
$\begin{array}{l}\text { Total suspended solids } \\
\text { (TSS) mg/L) }\end{array}$ & 751.33 & 35.2 \\
Settleable solids (ml/L) & 3 & - \\
\hline
\end{tabular}




\section{Conclusion}

In this study, the electrochemical treatment of swine slaughterhouse wastewater by EC using aluminum and iron electrodes was investigated. The effects of the different operational parameters on the removal of COD were analyzed. It was found that the use of aluminum, iron or the combination of both electrodes in EC could effectively reduce the COD of a swine slaughterhouse wastewater. The most effective was Al-Al followed by $\mathrm{Al}-\mathrm{Fe}$ and lastly by $\mathrm{Fe}-\mathrm{Fe}$ electrode arrangements. Moreover, electrode consumption increased with increasing current density wherein $\mathrm{Al}-\mathrm{Al}$ has the least metal consumption followed by Al-Fe and then by FeFe. Statistical analysis showed that electrode type, treatment time and electrode consumption were significantly different, thus, it must be considered in the design of EC process for swine slaughterhouse wastewater treatment. Likewise, the result of the effluent quality before and after treatment using a larger scale was within the standards making this a promising process for swine slaughterhouse wastewater treatment.

The authors would like to acknowledge Mapua University through DRIVE (Directed Research for Innovation and Value Enhancement) for the funding of this research as well as the representatives of Paranaque swine slaughterhouse for their assistance and permission to collect wastewater used in this study.

\section{References}

[1] M. Kobya, E. Senturk and M. Bayramoglu, J. Hazard. Mater. 133 (2006)

[2] H. S. Plumber and B. H. Kiepper, Bulgarian J. Agric. Sci. 16 (2010)

[3] M. Asselin, P. Drogui, H. Benmoussa and J. F. Blais, Chemosphere 72 (2008)

[4] K. Rajeshwar, J. G. Ibanez, and G. M. Swain, J. Appl. Electrochem. 24 (1994)

[5] M. Reilly, A. P. Cooley, D. Tito, S. A. Tassou and M. K. Theodorou, Energy Procedia 161 (2019)

[6] L. O. Paulista, P. H. Presumido, J. D. P. Theodoro, A. L. N. Pinheiro, Environ. Sci. Pollu. Res. 25 (2018)

[7] K. Eryuruk, U. Tezcan Un and U. Bakir Ogutveren, J. Clean. Prod. 172 (2018)

[8] H. M. Bui, Pol. J. Environ. Stud. 27 (2018)

[9] G. Guven, A. Perendeci, and A. Tanyolac, Chem. Eng. J. 151 (2009)

[10] X. Chen, G. Chen and P. L. Yue, J. Envi. Eng. $126(2000)$

[11] H. Moreno-Casillas, D. Cocke, J. Gomes, P. Morkovsky, J. R. Parga, and E. Peterson, J. Sep. Purif. Technol. 56 (2007)

[12] R. Katal and H. Pahlavanzadeh, Desalination 265 (2011)

[13] E. Butler, Y. Hung, R. Yu-Li Yeh and M. Al Ahmad, Water 3 (2011)

[14] M. Saleem, A. Bukhari and M. Akram, J. Basic Appl. Sci. 7 (2011)
[15] U. U. Tezcan, A. S. Koparal and U. B. Ogutveren, J. Hazard. Mater. 164 (2009)

[16] E. Bazrafshan, A. H. Mahvi, S. Nasseri and M. Shaighi, Iran. J. Environ. Health. Sci. Eng. 2 (2007)

[17] M. Mollah, R. Schennach, J. Parga and D. Cocke J. Hazard. Mater. B84 (2001)

[18] A. Bukhari, Biores. Technol. 99 (2008)

[19] A. Hannouche, G. Chebbo, G. Ruban, B. Tassin, B. J. Lemaire, and C. Joannis, Water Sci. Technol. 12 (2011) 